\title{
Multimedia Interaktif Berorientasi Model Problem Based Learning (PBL) Pada Muatan IPA
}

\section{Ni Luh Anggreni* ${ }^{*}$, I Nyoman Laba Jayanta ${ }^{2}$, Luh Putu Putrini Mahadewi ${ }^{3}$}

\author{
1,2,3 Universitas Pendidikan Ganesha, Singaraja, Indonesia
}

\section{ART ICLE INFO}

Article history:

Received March 09, 2021

Revised April 15, 2021

Accepted June 20, 2021

Available online August 25, 2021

Kata Kunci:

Multimedia Interaktif, Problem Based Learning

\section{Keywords:}

Interactive Multimedia, Problem Based Learning

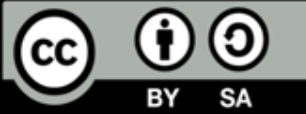

This is an open access article under the CC BY-SA license.

Copyright $(2021$ by Author. Published by Universitas Pendidikan Ganesha.

\begin{abstract}
A B S T R A K
Kurangnya kemampuan guru dalam mengembangkan media pembelajaran IPA berbasis teknologi yang mengintegrasikan model pembelajaran di dalamnya. Penelitian ini bertujuan untuk menghasilkan multimedia interaktif berorientasi model Problem Based Learning yang valid dan layak digunakan pada muatan IPA kelas $V$ sekolah dasar. Penelitian ini adalah penelitian pengembangan yang menggunakan model pengembangan 4D (Define, Design, Develop, dan Disseminate). Subjek dalam penelitian ini adalah 1 ahli materi pembelajaran, 1 ahli desain pembelajaran, 1 ahli media pembelajaran, 3 siswa untuk uji coba perorangan, dan 9 siswa untuk uji coba kelompok kecil. Pengumpulan data dilakukan menggunakan metode pencatatan dokumen berupa angket/kuesioner dan wawancara. Analisis data yang digunakan adalah teknik analisis deskriptif kualitatif dan deskriptif kuantitatif. Berdasarkan hasil penilaian oleh ahli desain pembelajaran, diperoleh persentase sebesar $90 \%$ dengan kualifikasi sangat baik, hasil penilaian oleh ahli media pembelajaran diperoleh persentase sebesar 90\% dengan kualifikasi sangat baik, hasil penilaian uji coba perorangan yang dilakukan oleh 3 orang siswa diperoleh hasil persentase keseluruhan sebesar $92 \%$ dengan kualifikasi sangat baik, hasil penilaian uji coba kelompok kecil yang dilakukan oleh 9 orang siswa diperoleh hasil persentase keseluruhan sebesar $94 \%$ dengan kualifikasi sangat baik. Berdasarkan hasil penelitian, dapat disimpulkan bahwa multimedia interaktif berorientasi model Problem Based Learning pada muatan IPA layak digunakan dalam proses pembelajaran.
\end{abstract}

\section{A BSTRACT}

Lack of teacher ability in developing technology-based science learning media that integrates learning models in it. This study aims to produce an interactive multimedia oriented Problem Based Learning model that is valid and suitable for use in the fifth grade science content of elementary schools. This research is development research that uses a 4D development model (Define, Design, Develop, and Disseminate). The subjects in this study were 1 learning material expert, 1 learning design expert, 1 learning media expert, 3 students for individual trials, and 9 students for small group trials. Data was collected using the document recording method in the form of a questionnaire/questionnaire and interviews. The data analysis used is descriptive qualitative and quantitative descriptive analysis techniques. Based on the results of the assessment by the learning design expert, the percentage of $90 \%$ with very good qualifications, the results of the assessment by the learning media expert obtained a percentage of $90 \%$ with very good qualifications, the results of the individual trial assessment conducted by 3 students obtained the overall percentage result of $92 \%$ with very good qualifications, the results of the small group trial assessment conducted by 9 students obtained an overall percentage result of $94 \%$ with very good qualifications. Based on the results of the study, it can be concluded that interactive multimedia oriented to the Problem-based learning model on science content is suitable for use in the learning process.

\section{PENDAHULUAN}

Covid 19 menyebabkan perubahan dalam sistem pendidikan di Indonesia, yang awalnya berbasis tatap muka langsung, yakni siswa dan guru bertemu langsung dalam proses pembelajaran di sekolah, berubah menjadi sistem pembelajaran daring (dalam jaringan) (Chang et al., 2020; Daheri et al., 2020; 
Permata \& Bhakti, 2020). Pembelajaran dengan sistem daring menuntut guru mampu membuat pembelajaran dapat berjalan dengan baik seperti biasa dengan situasi dan kondisi yang berbeda (Windhiyana, 2020; Yustina et al., 2020). Pada pembelajaran tatap muka langsung seluruh media dapat guru hadirkan secara nyata namun berbeda saat pembelajaran daring. Media yang awalnya bisa dihadirkan secara nyata berubah menjadi media visual yang menggabungkan beberapa jenis sumber belajar seperti dokumen, gambar, video, audio karena keterbatasan jarak. Pada masa pandemi saat ini, guru harus pandai dalam memilih media pembelajaran yang digunakan dalam proses pembelajaran, sehingga guru harus mempunyai inovasi agar siswa tidak jenuh, dan tujuan pembelajaran dapat tercapai dengan baik, sehingga dapat menumbuh kembangkan minat dan mendorong siswa untuk mau belajar agar dapat merubah kemampuan, sikap, atau perilaku yang positif Astani, 2020; (Pane \& Dasopang, 2017). Sehingga media pembelajaran yang ideal digunakan dalam proses pembelajaran daring saat ini adalah media pembelajaran yang berbasis TIK agar tujuan pembelajaran dapat tercapai dengan maksimal.

Namun, pada kenyataannya berdasarkan hasil wawancara dengan guru wali kelas ditemukan permasalahan bahwa guru merasa sulit untuk menghasilkan media pembejaran berbasis TIK karena keterbatasan waktu dan belum terlalu menguasi TIK. Oleh karean itu, dalam melaksanakan pembelajaran IPA guru lebih banyak menggunakan buku yang sudah dimiliki siswa atau mencari media pembelajaran berupa video di internet. Selain itu pula, berdasarkan hasil observasi yang dilakukan pada Pengenalan Lapangan Persekolahan berbasis Daring (PLPbD) bahwa dalam pembelajaran daring siswa kurang aktif jika hanya menyimak materi dari video yang berikan tanpa adanya media yang memungkinkan siswa melakukan kegiatan yang membuat siswa bisa menemukan sendiri pengetahuannya. Hasil penyebaran kuesioner yang diisi oleh 25 orang siswa dari 37 orang siswa, ditemukan hasil yakni a) 72\% siswa menyatakan guru lebih dominan menggunakan buku sebagai media, dalam pembelajaran muatan IPA, b) 80\% siswa menyatakan kurang memahami materi IPA jika hanya belajar lewat buku tanpa ada media seperti gambar atau video yang menarik, c) $88 \%$ siswa menyatakan guru menggunakan media berupa video yang berasal dari internet pada muatan IPA, d) $80 \%$ siswa merasa bosan jika hanya mendengarkan ceramah pada saat pemaparan materi, e) $80 \%$ siswa menyatakan guru belum menggunakan media yang mampu menyajikan materi dan menggabungkan model pembembelajaran, f) 88\% siswa menyatakan memerlukan media berbasis TIK yang mampu menyajikan materi IPA secara menarik dengan menggabungkan model pembelajaran. Kondisi tersebut jika terus dibiarkan tanpa diberikan solusi akan membuat proses pembelajaran tidak baik.

Salah satu upaya yang dapat dilaksanakan untuk mengatasi permasalahan yang terjadi yaitu mengembangkan media pembelajaran yang ideal dalam proses pembelajaran daring yakni media pembelajaran berbasis TIK. Salah satunya ialah multimedia interaktif berorientasi model pembelajaran Problem Based Learning (PBL). Multimedia memiliki pengaruh terhadap hasil belajar siswa.Multimedia merupakan media yang menarik (Erwin \& Yarmis, 2019; Herdiansyah et al., 2019; Margarita et al., 2018; Sanusi et al., 2015). Belum banyak kajian mendalam yang membahas mengenai multimedia interaktif berorientasi model pembelajaran Problem Based Learning (PBL). Multimedia interaktif merupakan salah satu alat teknologi informasi yang menunjang proses pembelajaran yang terdiri dari gabungan beberapa media seperti teks, grafis, gambar, audio, video dan animasi yang menyajikan informasi dan dilengkapi dengan alat kontro. Multimedia seperti ini bisa menciptakan proses belajar mengajar lebih aktif dan efektif karena adanya interaksi antara peserta didik dengan media yang digunakan (Diputra, 2016; Heo \& Toomey, 2020; Khan \& Masood, 2015; Knoop-van Campen et al., 2020). Multimedia dalam penelitian ini berorientasi pada model pembelajaran Problem Based Learning ( $P B L)$. Multimedia interaktif ini dapat menghadirkan pembelajaran yang menarik dan efektif, sehingga siswa aktif. Proses pembelajaran menjadi bermakna serta tercapainya tujuan pembelajaran secara maksimal karena tetap memerhatikan langkah langkah dan kaidah-kaidah model pembelajaran Problem Based Learning (PBL).

Beberapa penelitian yang sudah dilkukan sebelumnya anatara lain, penelitian yang menemukan bahwa media pembelajaran multimedia interaktif menggunakan Adobe Flash dalam bentuk permainan menjadi efektif dan layak digunakan dalam proses pembelajaran (Herdiansyah et al., 2019). Penelitian yang menyatakan bahwa media pembelajaran tematik telah valid (isi media sesuai kurikulum, desain dan layout menarik, kemudahan pengoperasian, bahasa mudah dipahami siswa, serta penyajian jelas sesuai karakteristik siswa), praktis (isi dan tujuan yang jelas, mudah dibaca, tampilan menarik, dan dapat meningkatkan minat siswa dalam pembelajaran), serta efektif (dapat meningkatkan aktivitas dan hasil belajar siswa) (Erwin \& Yarmis, 2019). Penelitian yang menyataan multimedia interaktif dapat membawa peserta didik untuk belajar secara tidak langsung dan dapat belajar secara mandiri (Margarita et al., 2018). Perbedaan penelitian ini dengan yang sudah ada adalah penelitian ini mengembangkan multimedia interaktif berorientasi pada model pembelajaran Problem Based Learning (PBL). Selain itu, pada pemaparan materi dilengkapi dengan video untuk mengorientasi siswa terhadap permasalahan yang diberikan, sehingga siswa bisa mengamati permasalahan dengan jelas. Penggunaan multimedia interaktif 
dengan berorientasi model pembelajaran Problem Based Learning (PBL) dapat meningkatkan hasil belajar siswa karena dapat menarik minat dan motivasi siswa untuk aktif mengikuti proses pembelajaran. Penggabungan media video, grafis, animasi, dan audio yang menarik berorientasi Problem Based Learning $(P B L)$ dapat mempermudah siswa mempelajari konsep serta masalah yang berkaitan dengan muatan IPA yang dapat meningkatkan kemampuan berpikir kritis, pemecahan masalah, kreativitas, keingintahuan, dan integritas siswa (Mashami \& Khaeruman, 2020; Han, 2019).

Tujuan penelitian ini adalah untuk menghasilkan multimedia interaktif berorientasi model Problem Based Learning yang valid dan layak digunakan pada muatan IPA kelas V Sekolah Dasar. Implikasi dari penelitian pengembangan multimedia interaktif berorientasi model Problem Based Learning pada muatan IPA adalah mendorong guru menjadi lebih kreatif dalam mengembangkan media dengan memanfaatkan kemajuan teknologi guna menciptakan pendidikan yang berkualitas. Selain itu, siswa dapat melakukan tayangan ulang pada materi tertentu untuk melihat gambaran yang lebih fokus dan nyata sesuai dengan prinsip belajar IPA. Melalui multimedia interaktif ini siswa lebih dimudahkan dalam pembelajaran. Multimedia interaktif yang dibuat diharapkan dapat membuat siswa memiliki sikap ilmiah yaitu berpikir kritis, memiliki rasa ingin tahu, ulet dan gigih, terbuka, mampu membedakan opini dan fakta, dan peduli terhadap lingkungan.

\section{METODE}

Pengembangan multimedia interaktif berorientasi model Problem Based Learning dikembangkan berdasarkan tahapan-tahapan model 4D, yang terdiri atas 4 tahap yaitu: Pendefinisian (Define), Perancangan (Design), Pengembangan (Develop), Penyebaran (Disseminate) (Tegeh dkk, 2019). Tahap pendefinisian bertujuan untuk menganalisis kebutuhan dan syarat-syarat pembelajaran dalam pengembangan multimedia interaktif berorientasi model Problem Based Learning. Dalam tahap ini terdapat 5 langkah untuk dapat mencari pokok permasalahan yang ada, yaitu: (1) analisis awal (front end analysis), (2) analisis peserta didik, (3) analisis tugas, (4) analisis konsep, dan (5) analisis tujuan pembelajaran. Tahap kedua adalah perancangan yang bertujuan untuk merancang multimedia interaktif berorientasi model Problem Based Learning yang dapat digunakan dalam pembelajaran muatan IPA. Pada tahap dilakukan pembembuatan outline konten, flowchart, desain awal, dan storyboard serta menyusun instrument penilaian media. Tahap ketiga adalah tahap pengembangan, pada tahap ini terdiri dari tahap produksi, implementasi dan evaluasi. Tahap terakhir adalah tahap penyebaran, pada tahap ini dilakukan penyebaran terbatas, hanya kepada kepala sekolah, guru kelas VA, dan siswa kelas V A SD Lab Undiksha.

Subjek uji coba dalam penelitian ini adalah 1 ahli materi, 1 ahli desain, dan 1 ahli media serta 12 orang siswa. Proses uji coba produk terlebih dahulu dinilai oleh para ahli yang terdiri dari ahli materi, ahli desain, dan ahli media pembelajaran. Selanjutnya, dilakukan uji coba terhadap siswa secara perorangan yang berjumlah 3 orang dan kelompok kecil yang berjumlah 9 orang. Metode pengumpulan data dalam penelitian ini, yaitu dengan kuesioner dan wawancara. Instrumen yang digunakan dalam penelitian ini berupa lembar validasi dari ahli materi, ahli desain dan ahli media, serta lembar uji coba perorangan dan kelompok kecil. Instrumen dalam penelitian pengembangan ini menggunakan skala bertingkat atau rating scale sesuai dengan kisi-kisi instrumen yang telah dibuat berdasarkan kajian pustaka terhadap produk yang dikembangkan. Selanjutnya, hasilnya dikonsultasikan dengan dosen pembimbing penelitian, sehingga instrumen yang dibuat siap digunakan untuk pengumpulan data penelitian. Kisi-kisi instrumen ditunjukkan pada tebel 1, 2, 3, dan 4. Jenis data dalam penelitian ini, yaitu data kualitatif dan kuantitatif. Dalam penelitian pengembangan ini metode dan teknik analisis data yang digunakan adalah analisis deskriptif kualitatif dan kuantitatif. Analisis deskriptif kualitatif digunakan untuk mengolah data yang bersumber dari komentar, tanggapan, kritik, dan saran berdasarkan uji para ahli, uji coba siswa secara perorangan dan uji coba kelompok kecil. Sedangkan analisis kuantitatif digunakan untuk mengetahui gambaran umum mengenai penyebaran data berupa skor yang sudah diperoleh dari lembar penilaian para ahli, uji coba perorangan dan uji coba kelompok. Untuk dapat memberikan makna dan pengambilan keputusan digunakan tabel konversi tingkat pencapaian dengan skala pada Tabel 5.

Tabel 1. Kisi-kisi Instrumen Ahli Materi Pembelajaran

\begin{tabular}{|c|c|c|c|c|}
\hline No. & Aspek & Indikator & Nomor Soal & Jumlah Buitr n \\
\hline \multirow{3}{*}{1} & \multirow{3}{*}{ Pembelajaran } & 1. Kompetensi dasar & 1 & 1 \\
\hline & & 2. Indikator & 2 & 1 \\
\hline & & 3. Tujuan pembelajaran & $3,4,5$ & 3 \\
\hline \multirow{2}{*}{2} & \multirow{2}{*}{ Materi } & 1. Penyajian materi & $6,7,8,9$ & 4 \\
\hline & & 2. Relevansi materi & $10,11,12,13$ & 4 \\
\hline
\end{tabular}




\begin{tabular}{|c|c|c|c|c|}
\hline No. & Aspek & Indikator & Nomor Soal & Jumlah Buitr n \\
\hline \multirow{4}{*}{3} & \multirow{4}{*}{ Tata Bahasa } & 1. Bahasa & 14 & 1 \\
\hline & & 2. Kebenaran istilah & 15 & 1 \\
\hline & & 3. Kebenaran ejaan & 16 & 1 \\
\hline & & 4. Penggunaan tanda baca & 17 & 1 \\
\hline \multicolumn{4}{|c|}{ Jumlah butir } & 17 \\
\hline
\end{tabular}

Tabel 2. Kisi-kisi Instrumen Ahli Desain Pembelajaran

\begin{tabular}{|c|c|c|c|c|}
\hline No & Aspek & Indikator & $\begin{array}{l}\text { Nomor } \\
\text { Soal }\end{array}$ & $\begin{array}{l}\text { Jumlah } \\
\text { Butir }\end{array}$ \\
\hline \multirow{3}{*}{1} & Ketepatan & 1. Kejelasan tema dengan tujuan pembelajaran & 1 & 1 \\
\hline & tema & 2. Kesesuaian tema dengan materi pembelajaran & 2 & 1 \\
\hline & Layout & 1. Kejelasan uraian Materi & 3 & 1 \\
\hline 2 & $\begin{array}{l}\text { penyajian } \\
\text { materi }\end{array}$ & $\begin{array}{l}\text { 2. Penyajian materi berorientasi pada model } \\
\text { pembelajaran Problem Based Learning }\end{array}$ & 4 & 1 \\
\hline \multirow{2}{*}{3} & Intaraktivitac & 1. Mendorong siswa untuk melakukan interaksi & 5 & 1 \\
\hline & Interaktıvitas & 2. Menarik motivasi belajar & 6 & 1 \\
\hline \multirow{5}{*}{4} & & 1. Keterkaitan pertanyaan dengan materi & 7 & 1 \\
\hline & Kualitas & 2. Pertanyaan mudah dimengerti & 8 & 1 \\
\hline & pertanyaan & 3. Tingkatan kesulitan pertanyaan & 9 & 1 \\
\hline & & 4. Kejelasan petunjuk pengerjaan latihan soal & 10 & 1 \\
\hline & & Jumlah butir & & 10 \\
\hline
\end{tabular}

Tabel 3. Kisi-kisi Instrumen Ahli Media Pembelajaran

\begin{tabular}{|c|c|c|c|c|}
\hline No. & Aspek & Indikator & Nomor Butir & Jumlah Butir \\
\hline & & 1. Ketepatan faktual & 1 & 1 \\
\hline \multirow[t]{2}{*}{1} & Pembelajaran & 2. Petunjuk penggunaan & 2 & 1 \\
\hline & & 1. Kesesuaian program & 3 & 1 \\
\hline \multirow[t]{6}{*}{2} & Pemograman & 2. Penggunaan tombol & $4,5,6$ & 3 \\
\hline & & 1. Huruf & $7,8,9$ & 3 \\
\hline & & 2. Animasi & 10,11 & 2 \\
\hline & & 3. Video & $12,13,14$ & 3 \\
\hline & & 4. Audio & $15,16,17,18$ & 4 \\
\hline & & 5. Gambar & 19,20 & 2 \\
\hline \multirow[t]{4}{*}{3} & Tampilan & 6. Tata letak & 21,22 & 2 \\
\hline & & 7. Warna background & 23,24 & 2 \\
\hline & & 8. Kemasan produk & 25 & 1 \\
\hline & & Jumlah butir & & 25 \\
\hline
\end{tabular}

Tabel 4. Kisi-kisi Instrumen Uji Perorangan dan Uji Kelompok Kecil

\begin{tabular}{|c|c|c|c|c|}
\hline No. & Aspek & Indikator & Nomor Butir & $\begin{array}{l}\text { Jumlah } \\
\text { Butir }\end{array}$ \\
\hline \multirow{6}{*}{1} & & Kompetensi Dasar & 1 & 1 \\
\hline & Pembelajaran & Indikator pembelajaran & 2 & 1 \\
\hline & & Tujuan Pembelajaran & 3 & 1 \\
\hline & & Materi & $4,5,6$ & 3 \\
\hline & & Bahasa & 7 & 1 \\
\hline & & Tampilan media & 8 & 1 \\
\hline \multirow[t]{2}{*}{2} & Kualitas & Media dapat memotivasi dalam pembelajaran & 9,10 & 2 \\
\hline & & Soal yang disajikan sesuai dengan materi & 11 & 1 \\
\hline \multirow[t]{2}{*}{3} & Evaluasi & Petunjuk pengerjaan soal jelas & 12 & 1 \\
\hline & & Media mudah digunakan & 13 & 1 \\
\hline \multirow[t]{2}{*}{4} & Aksesbilitas & Petunjuk penggunaan media jelas & 14 & 1 \\
\hline & & Jumlah butir & & 14 \\
\hline
\end{tabular}


Tabel 5. Konversi Tingkat Pencapaian dengan Skala 5

\begin{tabular}{|c|c|c|}
\hline Tingkat Pencapaian & Kualifikasi & Keterangan \\
\hline $90-100$ & Sangat baik & Tidak perlu direvisi \\
\hline $75-89$ & Baik & Sedikit direvisi \\
\hline $65-79$ & Cukup & Direvisi secukupnya \\
\hline $55-64$ & Kurang & Banyak hal yang direvisi \\
\hline $1-54$ & Sangat kurang & Diulangi membuat produk \\
\hline
\end{tabular}

\section{HASIL DAN PEMBAHASAN}

Hasil

Hasil dari penelitian pengembangan ini adalah sebuah produk multimedia interaktif berorientasi model Problem Based Learning yang dikembangkan berdasarkan tahapan- tahapan model pengembangan 4D dan telah melalui beberapa tahap uji coba serta sudah dilakukan revisi menurut saran dan kritik masukan yang diberikan. Proses pengembangan produk multimedia interaktif berorientasi model Problem Based Learning dikembangkan berdasarkan tahapan-tahapan model 4D, yang terdiri atas 4 tahap yaitu: Pendefinisian (Define), Perancangan (Design), Pengembangan (Develop), Penyebaran (Disseminate) (Diani, 2015).

\section{Pendefinisian (Define)}

Tahap pendefinisian bertujuan untuk menganalisis kebutuhan dan syarat-syarat pembelajaran dalam pengembangan multimedia interaktif berorientasi model Problem Based Learning. Dalam tahap ini terdapat 5 langkah untuk dapat mencari pokok permasalahan yang ada, yaitu: (1) Analisis awal (front end Analysis) pada tahap ini dilakukan wawancara dengan guru wali kelas V A di SD Lab Undiksha ditemukan kendala dalam pembuatan media pembelajaran yang berbasis kemajuan teknologi. (2) Analisis peserta didik, pada tahap ini, ditemukan bahawa siswa kurang memahami materi IPA jika hanya belajar lewat buku tanpa ada media seperti gambar atau video yang menarik. (3) Analisis tugas, pada tahap ini dilakukan analisis terhadap kompetensi dasar (KD) 3.7 Menganalisis pengaruh kalor terhadap perubahan suhu dan wujud benda dalam kehidupan sehari-hari dan indikator pencapaian kompotensi 3.7.1 Menjelaskan pengertian perubahan wujud benda dan 3.7.1 Mengidentifikasi perubahan wujud benda. (4) Analisis konsep, pada tahap ini dilakukan analisis terhadap materi yang dikembangkan, yaitu perubahan wujud benda. (5) Analisis tujuan pembelajaran, adapun tujuan pembelajaran berdasarkan analisis yang telah dilakukan adalah (1) Dengan multimedia interaktif berorientasi model Problem Based Learning (PBL), siswa dapat menjelaskan pengertian perubahan wujud benda dengan benar. (2) Dengan menyimak multimedia interaktif berorientasi model Problem Based Learning (PBL), siswa dapat mengidentifikasi perubahan wujud benda dengan tepat.

\section{Tahap Perancangan (Design)}

Tahap kedua adalah tahap perancangan yang bertujuan untuk merancang multimedia interaktif berorientasi model Problem Based Learning pada materi perubahan wujud benda. Tahap ini diawali dengan yaitu membuat outline konten. Dalam penelitian ini, outline konten yang dibuat adalah berupa teks yang bertujuan untuk memberikan informasi konten yang dimuat dalam produk yang dikembangkan. Langkah selanjutnya adalah membuat flowchart yang merupakan suatu alur program yang dibuat mulai dari pembuka (start), isi, sampai dengan penutup (exit/quit) dan dilanjutkan dengan membuat desain awal berupa bentuk dasar yang bertujuan mempermudah dalam pengembangan produk. Selanjutnya, merancang storyboard yang berisi berisi semua informasi yang akan tampil pada layar dan informasi pendukung yang akan membantu pengembang multimedia dalam mengembangkan komponen multimedia interaktif. Langkah terakhir adalah menyusun instrumen penilaian media berupa kuesioner yang digunakan untuk mengetahui validitas produk yang sudah dikembangkan. 


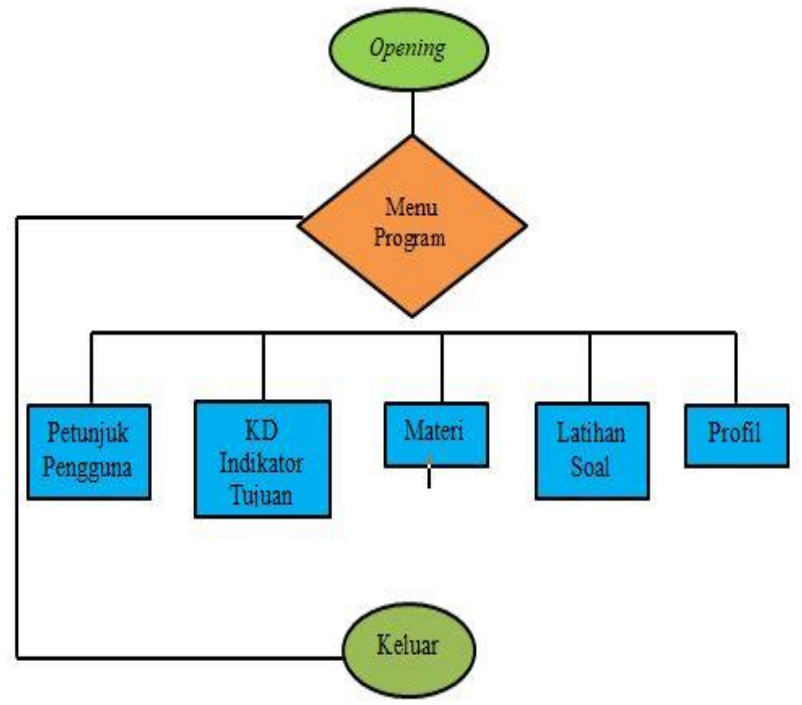

Gambar 1. Flowcart

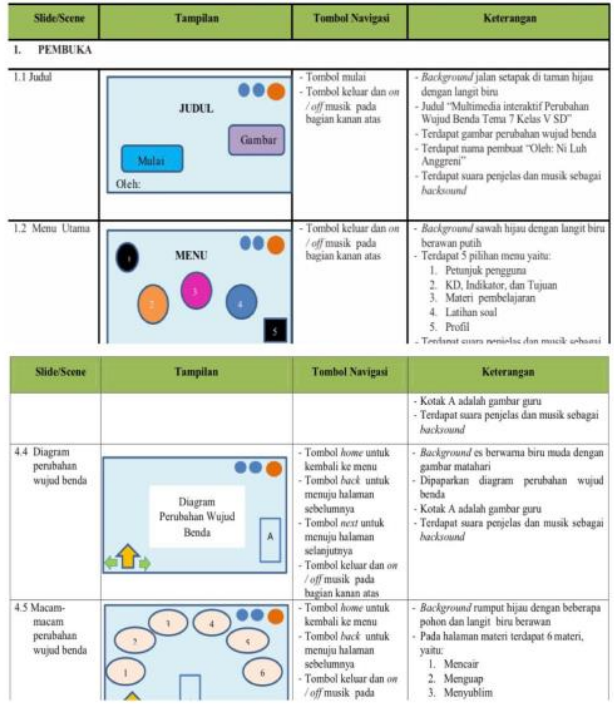

Gambar 2. Storyboard

\section{Tahap Pengembangan (Develop)}

Tahap ketiga adalah tahap pengembangan. Tahap pengembangan terdiri dari tahap produksi, implementasi, dan evaluasi. Pada tahap produksi pengembangan produk multimedia interaktif berorientasi model Problem Based Learning pada muatan IPA berdasarkan storyboard yang sudah dirancang. Setelah produk dikembangkan, dilanjutkan pada tahap implementasi yaitu menguji coba produk yang terlebih dahulu dinilai oleh para ahli yang terdiri dari ahli materi, ahli desain dan ahli media pembelajaran yang kemudian di uji coba terhadap siswa secara perorangan dan kelompok kecil. Tahap ini bertujuan untuk mengetahui kelayakan produk yang sudah dibuat. Tahap terakhir adalah tahap evaluasi. Pada tahap ini dilakukan revisi produk berdasarkan uji ahli dan siswa. Tahap ini bertujuan untuk menyempurnakan produk yang dikembangkan.

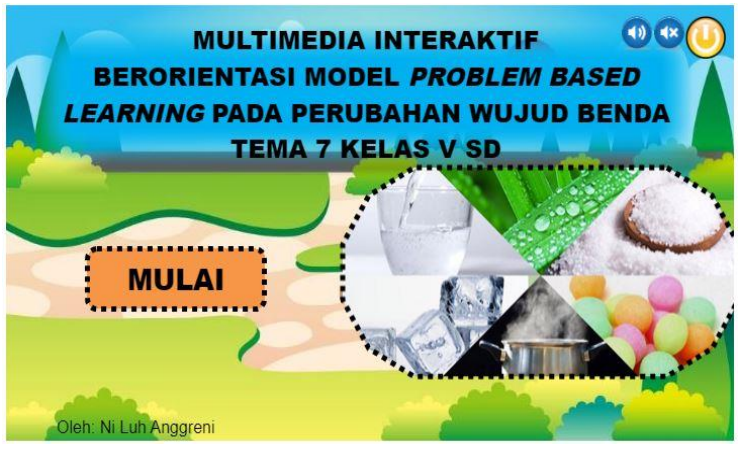

Gambar 3. Tampilan judul

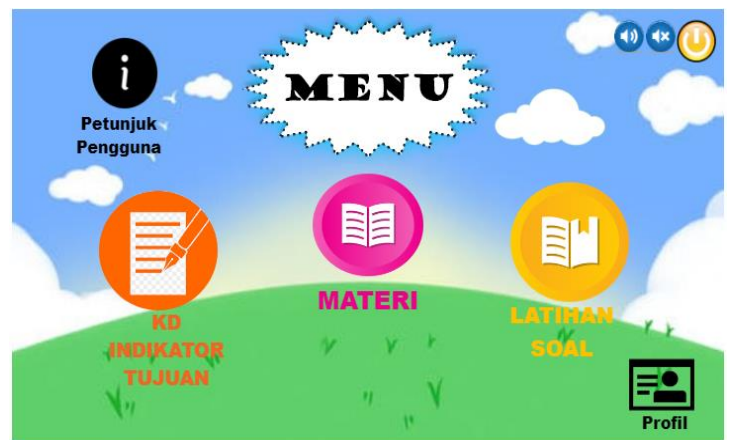

Gambar 4. Tampilan Menu

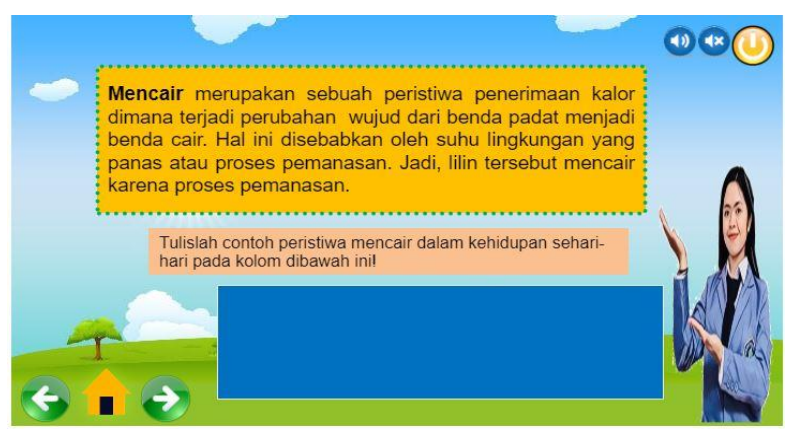

Gambar 5. Tampilan materi

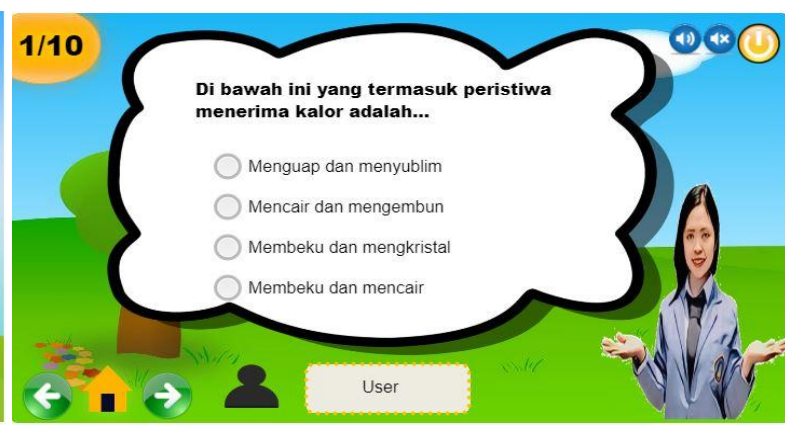

Gambar 6. Tampilan soal 
Tabel 6. Hasil Uji Coba Media

\begin{tabular}{cccc}
\hline Subjek Uji Coba & Pencapaian & Kualifikasi & Keterangan \\
\hline Ahli materi & 98 & Sangat baik & Tidak perlu direvisi \\
Ahli desain & 90 & Sangat baik & Tidak perlu direvisi \\
Ahli media & 90 & Sangat baik & Tidak perlu direvisi \\
$\begin{array}{c}\text { Uji coba perorangan } \\
\text { Uji coba kelompok } \\
\text { kecil }\end{array}$ & 92 & Sangat baik & Tidak perlu direvisi \\
\hline
\end{tabular}

\section{Tahap Penyebaran (Disseminate)}

Tahap penyebaran, merupakan tahap terakhir yang bertujuan untuk menyebarkan produk pengembangan multimedia interaktif berorientasi model Problem Based Learning pada muatan IPA yang sudah terbukti validitasnya (Diani, 2015). Pada penelitian ini hanya dilakukan penyebaran terbatas, berupa link (html5) kepada kepala sekolah, guru kelas VA, dan siswa kelas V A SD Lab Undiksha.

\section{Pembahasan}

Tahap pertama ialah tahap define (tahap pendefinisian) dengan tujuan untuk menganalisis kebutuhan dan syarat-syarat pembelajaran dalam pengembangan multimedia interaktif berorientasi model Problem Based Learning. Pada tahap ini terdapat 5 langkah untuk dapat mencari pokok permasalahan yang ada, yaitu: (1) Analisis awal (front end Analysis) pada tahap ini dilakukan wawancara dengan guru wali kelas V A di SD Lab Undiksha ditemukan kendala dalam pembuatan media pembelajaran yang berbasis kemajuan teknologi. (2) Analisis peserta didik, pada tahap ini, ditemukan bahawa siswa kurang memahami materi IPA jika hanya belajar lewat buku tanpa ada media seperti gambar atau video yang menarik. (3) Analisis tugas, pada tahap ini dilakukan analisis terhadap kompetensi dasar (KD) 3.7 Menganalisis pengaruh kalor terhadap perubahan suhu dan wujud benda dalam kehidupan sehari-hari dan indikator pencapaian kompotensi 3.7.1 Menjelaskan pengertian perubahan wujud benda dan 3.7.1 Mengidentifikasi perubahan wujud benda. (4) Analisis konsep, pada tahap ini dilakukan analisis terhadap materi yang dikembangkan, yaitu perubahan wujud benda. (5) Analisis tujuan pembelajaran. Pada tahap ini sangat perlu dilakukan untuk mengetahui kebutuhan akan solusi atas permasalahan tersebut (Erwin \& Yarmis, 2019; Qistina et al., 2019). Berdasarkan keseluruhan analisis yang sudah dilakukan pada tahap pendefinisian, dapat dinyatakan bahwa multimedia interaktif berorientasi model Problem Based Learning layak untuk dikembangkan. Multimedia interaktif berorientasi model Problem Based Learning merupakan salah satu media berbasis teknologi informasi yang menunjang proses pembelajaran yang sesuai dengan tahapan pembelajaran model model Problem Based Learning yang terdiri dari gabungan beberapa media seperti teks, grafis, gambar, audio, video dan animasi yang menyajikan informasi serta dilengkapi dengan alat kontrol sehingga bisa menciptakan proses belajar mengajar lebih aktif dan efektif karena adanya interaksi antara peserta didik dengan media yang digunakan (Diputra, 2016; Heo \& Toomey, 2020; Khan \& Masood, 2015; Knoop-van Campen et al., 2020).

Tahap kedua yakni define (perancangan). Pada tahap ini bertujuan untuk merancang multimedia interaktif berorientasi model Problem Based Learning pada materi perubahan wujud benda (Diani, 2015; Tegeh et al., 2019). Tahap ini diawali dengan yaitu membuat outline konten. Hal ini dilakukan untuk membuat kerangka awal yang merupakan rencana pengembangan yang memuat garis-garis besar dari konten yang akan digarap dan merupakan rangkaian ide-ide yang disusun secara sistematis, logis, jelas, terstruktur dan teratur. Dalam penelitian ini, outline konten yang dibuat adalah berupa teks yang bertujuan untuk memberikan informasi konten yang dimuat dalam produk yang dikembangkan. Selanjutnya, dibuat flowchart yang merupakan suatu alur program yang dibuat mulai dari pembuka (start), isi, sampai dengan penutup (exit/quit). Hal ini dilakukan untuk membantu pengembang dan juga programmer dalam menjelaskan proses-proses yang nantinya harus dilakukan oleh sebuah program atau peneliti pengembangan. Selanjutnya, dibuat desain awal yang berguna untuk dasar rancangan pengembangan media ini sebelum akhirnya dilakukan tahap pengembangan. Desain awal ini berupa bentuk dasar yang bertujuan mempermudah dalam pengembangan produk. Selanjutnya ialah merancang storyboard. Hal ini penting guna menuangkan alur-alur multimedia interaktif yang akan dikembangkan. Storyboad yang dibuat ini berisi semua informasi yang akan tampil pada layar dan informasi pendukung yang akan membantu pengembang multimedia dalam mengembangkan komponen multimedia interaktif (Mashami \& Khaeruman, 2020). Langkah terakhir adalah menyusun instrumen penilaian media berupa kuesioner yang digunakan untuk mengetahui validitas produk yang sudah dikembangkan.

Tahap ketiga yakni develop (tahap pengembangan). Tahap pengembangan terdiri dari tahap produksi, implementasi, dan evaluasi. Pada tahap produksi pengembangan produk multimedia interaktif berorientasi model Problem Based Learning pada muatan IPA berdasarkan storyboard yang sudah 
dirancang. Setelah produk dikembangkan, dilanjutkan pada tahap implementasi yaitu menguji coba produk yang terlebih dahulu dinilai oleh para ahli yang terdiri dari ahli materi, ahli desain dan ahli media pembelajaran yang kemudian di uji coba oleh siswa secara perorangan dan kelompok kecil. Tahap ini bertujuan untuk mengetahui kelayakan produk yang sudah dibuat. Berdasarkan hasil penilaian oleh ahli materi pembelajaran, diperoleh persentase sebesar $98 \%$ dengan kualifikasi sangat baik dan tidak perlu direvisi. Persentase 98\% dapat dicapai karena aspek materi dalam multimedia interaktif berorientasi model Problem Based Learning sudah mencakup aspek pembelajaran, materi, dan tata bahasa. Dalam membuat multimedia interaktif harus memerhatikan kesesuaian antara aspek pembelajaran, materi, dan tata bahasa karena itu semua saling berkaitan untuk menciptakan media multimedia interaktif yang baik (Mustofa \& Syafi'ah, 2018; Tegeh et al., 2019).

Berdasarkan hasil penilaian oleh ahli desain pembelajaran, diperoleh persentase sebesar $90 \%$ dengan kualifikasi sangat baik dan tidak perlu direvisi. Persentase sebesar $90 \%$ dapat dicapai karena dipengaruhi beberapa hal yang tercantum dalam multimedia interaktif yang dikembangkan, yaitu (1) kejelasan tema dengan tujuan dan materi, (2) kejelasan uraian materi, (3) penyajian materi sudah berorientasi model Problem Based Learning, (4) mendorong siswa untuk melakukan interaksi, (6) menarik motivasi belajar siswa, dan (7) terdapat pertanyaan sebagai evaluasi siswa. Desain pembelajaran memegang peranan yang sangat penting untuk meningkatan kualitas pembelajaran (Gafur, 2012; Setiawan, 2020). Multimedia interaktif berorientasi model pembelajaran Problem Based Learning (PBL) yang dikembangkan didesain sedemekian rupa agar materi yang disajikan dapat tersampaikan dnegan baik oleh siswa dan mampu memberikan daya tarik tersendiri kepada siswa untuk belajar lewat sajian materi audio visual. Materi pembelajaran berupa teks atau abstrak akan lebih sulit untuk dipahami oleh siswa jika divisualisasikan dengan gambar akan mampu memudahkan dalam mengingat pesan dan dapat meningkatkan motivasi siswa (Rosnihayati, 2017; Sudarma et al., 2015). Aspek desain antara lain: 1) Ketepatan tema, 2) Layout penyajian materi, 3) Interaktivitas, dan 4) kualitas pertanyaan.

Hasil analisis berdasarkan penilaian ahli media pembelajaran menunjukkan media yang dikembangkan layak dengan persentase sebesar $90 \%$ yang berada pada kualifikasi sangat baik dan tidak perlu direvisi. Persentase $90 \%$ dapat dicapai karena media yang dikembangkan memenuhi unsur multimedia interaktif dan tahap produk dalam pengembangan ini sudah berorientasi pada model Problem Based Learning. Unsur multimedia interaktif pada produk ini terdiri dari beberapa media seperti teks, gambar, audio, video dan animasi yang menyajikan informasi dan dilengkapi dengan alat kontrol yang memungkin terjadinya interaksi. Hal ini sesuai dengan pernyataan multimedia interaktif merupakan kombinasi dari beberapa media seperti teks, grafis, audio, video dan animasi yang bisa digunakan sebagai sebuah media pembelajaran yang dapat menyajikan informasi agar tercipta sebuah interaksi dua arah antara pengguna dengan media yang digunakanya (Gunawam et al., 2015; Nopriyanti \& Sudira, 2015; Qistina et al., 2019). Pada penyajiannya multimedia interaktif ini sudah berorientasi model Problem Based Learning dengan mengangkat permasalahan sebagai bahan pembelajaran, lalu pengguna mencoba menyelesaikan permasalahan dan tersedia refleksi mengenai hasil penyelesaian masalah. Problem Based Learning (PBL) merupakan suatu model pembelajaran. Peserta didik dihadapkan pada masalah autentik (nyata), sehingga diharapkan dapat menyusun pengetahuannya sendiri, menumbuhkembangkan keterampilan tingkat tinggi dan inkuiri, memandirikan siswa, dan meningkatkan kepercayaan dirinya (Haji et al., 2015; Nuswowati et al., 2017).

Setelah melewati uji ahli, selanjutnya produk diuji coba kepada siswa. Tahap uji coba kepada siswa terdiri dari 2 tahap, yaitu uji coba perorangan dan uji coba kelompok kecil. Berdasarkan hasil penilaian uji coba perorangan yang dilakukan oleh 3 orang siswa, diperoleh hasil persentase keseluruhan sebesar 92\% dengan kualifikasi sangat baik dan tidak ada saran yang bersifat revisi sehingga produk tidak perlu direvisi. Selanjutnya, berdasarkan hasil penilaian uji coba kelompok kecil yang dilakukan oleh 9 orang siswa, diperoleh hasil persentase keseluruhan sebesar 94\% dengan kualifikasi sangat baik dan tidak ada saran yang bersifat revisi sehingga produk tidak perlu direvisi. Pencapaian persentase tersebut dikarenakan multimedia interaktif ini dibuat dengan penyajian materi berupa teks, gambar, video, audio dan animasi semenarik mungkin dan agar mudah digunakan dalam proses pembelajaran. Hal tersebut juga diperkuat oleh pendapat siswa antara lain (1) materi mudah dipahami, (2) media pembelajaran sangat menyenangkan, (3) media pembelajaran menari, dan (4) media mudah dipelajari dimana saja karena bisa dibuka di HP. Pada penyajiannya, multimedia interaktif ini juga sudah berorientasi model Problem Based Learning dengan mengangkat permasalahan sebagai bahan pembelajaran, lalu pengguna mencoba menyelesaikan permasalahan dan tersedia refleksi mengenai hasil penyelesaian masalah (Asyari et al., 2016; Priani et al., 2019; Yahya, 2014). Hal ini menjadikan siswa lebih aktif dan menemukan sendiri pengetahuannya (Liew et al., 2017). Proses pembelajaran ini sesuai dengan karakteristik pembelajaran IPA pada Kurikulum 2013 yaitu siswa berproses aktif, siswa lebih banyak melakukan, dan guru memfasilitasi. Berdasarkan keseluruhan hasil baik dari uji ahli maupun uji coba siswa produk multimedia 
berorientasi model Problem Based Learning pada muatan IPA didapatkan skor dengan rentangan 90\%98\% dengan kualifikasi sangat baik dan valid atau layak digunakan dalam proses pembelajaran.

Tahap selanjutnya ialah dessiminate (tahap penyebaran) yang bertujuan untuk menyebarkan produk pengembangan multimedia interaktif berorientasi model pembelajaran Problem Based Learning pada muatan IPA (Diani, 2015). Pada penelitian ini hanya melakukan penyebaran terbatas yang berupa link (html5) kepada kepala sekolah, guru kelas VA, dan siswa kelas V A SD Lab Undiksha. Kelebihan dari penelitian pengembangan multimedia interaktif berorientasi model Problem Based Learning pada muatan IPA adalah menjadikan pembelajaran daring sesuai dengan prinsip belajar IPA. Siswa dapat melakukan tayangan ulang pada fenomena atau materi tertentu untuk melihat gambaran yang lebih fokus dan nyata (Susilowati \& Muryati, 2021). Selain itu, multimedia interaktif ini praktis untuk digunakan baik oleh guru maupun oleh siswa secara mandiri karena dapat diakses di melalui Handphone yang terhubung dengan internet (Han, 2019). Kekurangan penelitian pengembangan multimedia interaktif berorientasi model Problem Based Learning pada muatan IPA adalah belum melakukan uji keefektifan karena keterbatasan waktu di tengah kondisi pandemi covid-19. Direkomendasikan kepada peneliti lain agar melanjutkan penelitian ini untuk mengetahui keefektifan media.

\section{SIMPULAN}

Multimedia interaktif berorientasi model Problem Based Learning pada muatan IPA dapat dikatakan layak untuk digunakan dalam proses pembelajaran dengan kategori sangat baik dilihat dari indikator penilaian ahi materi, ahli desain, ahli media dan uji coba siswa secara perorangan dan kelompok kecil. Disarankan agar multimedia interaktif berorientasi model Problem Based Learning pada muatan IPA dapat dimanfaatkan secara optimal oleh siswa, baik saat pembelajaran bersama guru ataupun saat belajar mandiri di rumah. Untuk pengembangan penelitian lebih lanjut, diharapkan untuk melakukan uji keefektipan media ini. Dengan multimedia interaktif ini, disarankan agar siswa lebih semangat dan termotivasi dalam mengikuti pembelajaran. Selain itu, multimedia interaktif yang dibuat juga diharapkan dapat membuat siswa memiliki sikap ilmiah, yaitu berpikir kritis, memiliki rasa ingin tahu, ulet dan gigih, terbuka, mampu membedakan opini dan fakta, dan peduli terhadap lingkungan.

\section{DAFTAR PUSTAKA}

Asyari, M., Henie, M., Muhdhar, I. Al, \& Ibrahim, H. S. (2016). Improving Critical Thinking Skills through the Integration of Problem Based Learning and Group Investigation. International Journal for Lesson and Learning Studies, 5(1), 36-44. https://dx.doi.org/10.1108/IJLLS-10-2014-0042.

Chang, T. Y., Hong, G., Paganelli, C., Phantumvanit, P., Chang, W. J., Shieh, Y. S., \& Hsu, M. L. (2020). Innovation of Dental Education during COVID-19 Pandemic. Journal of Dental Sciences, 155. https://doi.org/10.1016/j.jds.2020.07.011.

Daheri, M., Juliana, J., Deriwanto, D., \& Amda, A. D. (2020). Efektifitas WhatsApp sebagai Media Belajar Daring. Jurnal Basicedu, 4(4), 775-783. https://doi.org/10.31004/basicedu.v4i4.445.

Diani, R. (2015). Pengembangan Perangkat Pembelajaran Fisika Berbasis Pendidikan Karakter dengan Model Problem Based Instruction. Jurnal Ilmiah Pendidikan Fisika Al-Biruni, 4(2), 243-255. https://doi.org/10.24042/jpifalbiruni.v4i2.96.

Diputra, K. S. (2016). Pengembangan Multimedia Pembelajaran Tematik Integratif untuk Siswa Kelas IV Sekolah Dasar. JPI (Jurnal Pendidikan Indonesia), 5(2), 125. https://doi.org/10.23887/jpiundiksha.v5i2.8475.

Erwin, V. A., \& Yarmis, Y. (2019). Multimedia Interaktif Bermuatan Permainan Edukatif di Kelas V Sekolah Dasar. Jurnal Basicedu, 3(2), 901-908. https://doi.org/10.31004/basicedu.v3i3.183.

Gafur, A. (2012). Desain Pembelajaran Konsep, Model, dan Aplikasinya dalam Perencanaan Pelaksanaan Pembelajaran. Penerbit Ombak.

Gunawam, G., Harjono, A., \& Sutrio, S. (2015). Multimedia Interaktif dalam Pembelajaran Konsep Listrik Bagi Calon Guru. Jurnal Pendidikan Fisika Dan Teknologi, 1(1), 9-14. https://dx.doi.org/10.29303/jpft.v1i1.230.

Haji, A. G., Safriana, \& Safitri, R. (2015). The Use of Problem Based Learning to Increase Students' Learning Independent and to Investigate Students' Concept Understanding on Rotational Dynamic at Students of SMA Negeri 4 Banda Aceh. Jurnal Pendidikan IPA Indonesia, 4(1), 67-72. https://doi.org/10.15294/jpii.v4i1.3503.

Han, Y. (2019). Exploring Multimedia, Mobile Learning, and Place-Based Learning in Linguacultural Education. Language Learning \& Technology, 23(3), 29-38. http://hdl.handle.net/10125/44692. 
Heo, M., \& Toomey, N. (2020). Learning with Multimedia: The Effects of Gender, Type of Multimedia Learning Resources, and Spatial Ability. Computers and Education, 146, 103747. https://doi.org/10.1016/j.compedu.2019.103747.

Herdiansyah, H., Cholily, Y. M., \& Cahyono, H. (2019). The Development of Interactive Instructional Media Using Adobe Flash in a Form of Game on the Geometry Lesson (Cube and Cuboid) for Secondary School. Mathematics Education Journal, 3(1), 32. https://doi.org/10.22219/mej.v3i1.8418.

Khan, F. M. A., \& Masood, M. (2015). The Effectiveness of an Interactive Multimedia Courseware with Cooperative Mastery Approach in Enhancing Higher Order Thinking Skills in Learning Cellular Respiration. Procedia - Social and Behavioral Sciences, 176, 977-984. https://doi.org/10.1016/j.sbspro.2015.01.567.

Knoop-van Campen, C. A. N., Segers, E., \& Verhoeven, L. (2020). Effects of Audio Support on Multimedia Learning Processes and Outcomes in Students with Dyslexia. Computers and Education, 150(February), 103858. https://doi.org/10.1016/j.compedu.2020.103858.

Liew, T. W., Mat Zin, N. A., \& Sahari, N. (2017). Exploring the Affective, Motivational and Cognitive Effects of Pedagogical Agent Enthusiasm in a Multimedia Learning Environment. Human-Centric Computing and Information Sciences, 7(1). https://doi.org/10.1186/s13673-017-0089-2.

Margarita, N., Harjono, N., \& Airlanda, G. S. (2018). Pengembangan Multimedia Interaktif sebagai Alat Bantu Pembelajaran dengan Model Pbl untuk Peningkatan Hasil Belajar Matematika. Journal for Lesson and Learning Studies, 1(3), 243-257. https://doi.org/10.23887/jlls.v1i3.15388.

Mashami, R. A., \& Khaeruman. (2020). Pengembangan Multimedia Interaktif Hidrolisis Garam Berbasis Problem Based Learning untuk Penumbuhan Keterampilan Generik Sains Siswa. JPIn: Jurnal Pendidik Indonesia, 8(2), 1-10. https://doi.org/10.47165/jpin.v2i2.71.

Mustofa, R., \& Syafi'ah, R. (2018). Pengembangan Media Pembelajaran Pop Up Book Materi Kenampakan Permukaan Bumi Mata Pelajaran IPA Kelas III SD. ELSE (Elementary School Education Journal), 2, 30-41. https://dx.doi.org/10.30651/else.v2i2.1723.

Nopriyanti, N., \& Sudira, P. (2015). Pengembangan Multimedia Pembelajaran Interaktif Kompetensi Dasar Pemasangan Sistem Penerangan dan Wiring Kelistrikan di SMK. Jurnal Pendidikan Vokasi, 5(2). https: //doi.org/10.21831/jpv.v5i2.6416.

Nuswowati, M., Susilaningsih, E., Ramlawati, \& Kadarwati, S. (2017). Implementation of Problem-Based Learning with Green Chemistry Vision to Improve Creative Thinking Skill and Students' Creative Actions. Jurnal Pendidikan IPA Indonesia, 6(2), 221-228. https://doi.org/10.15294/jpii.v6i2.9467.

Pane, A., \& Dasopang, M. D. (2017). Belajar dan Pembelajaran Aprida Pane Muhammad Darwis Dasopang. Fitrah, 03(2), 333-352. https://doi.org/10.24952/fitrah.v3i2.945.

Permata, A., \& Bhakti, Y. B. (2020). Keefektifan Virtual Class dengan Google Classroom dalam Pembelajaran Fisika di Masa Pandemi Covid-19. JIPFRI (Jurnal Inovasi Pendidikan Fisika Dan Riset Ilmiah), 4(1), 27-33. https://doi.org/10.30599/jipfri.v4i1.669.

Priani, I., Manuaba, I. B. S., \& Darsana, I. W. (2019). Pengaruh Model Problem Based Learning (PBL) Berbantuan Media Gambar terhadap Hasil Belajar IPA Siswa Kelas V Gugus III Kuta Utara Tahun Pelajaran 2017/2018. Mimbar PGSD, 7(1). https://dx.doi.org/10.23887/jjpgsd.v7i1.16972.

Qistina, M., Alpusari, M., Noviana, E., \& Hermita, N. (2019). Pengembangan Multimedia Interaktif Mata Pelajaran IPA Kelas IVc SD Negeri 034 Taraibangun Kabupaten Kampar. Primary: Jurnal Pendidikan Guru Sekolah Dasar, 8(2), 148. https://doi.org/10.33578/jpfkip.v8i2.7649.

Rosnihayati. (2017). Penggunaan Media Gambar untuk Meningkatkan Hasil Belajar IPS Siswa Kelas II SDN 003 Pagaran Tapah Darussalam Kabupaten Rokan Hulu. Primary: Jurnal Pendidikan Guru Sekolah Dasar, 6(1), 306-313.

Sanusi, S., Suprapto, E., \& Apriandi, D. (2015). Pengembangan Multimedia Interaktif sebagai Media Pembelajaran pada Pokok Bahasan Dimensi Tiga di Sekolah Menengah Atas (Sma). JIPM (Jurnal Ilmiah Pendidikan Matematika), 3(2), 398-416. https://doi.org/10.25273/jipm.v3i2.510.

Setiawan, A. R. (2020). Desain Pembelajaran Tematik untuk Membimbing Siswa Sekolah Dasar dalam Memperoleh Literasi Saintifik. Journal of Petrology, 369(1), 1689-1699. https: //doi.org/10.1017/CB09781107415324.004.

Sudarma, I. ., Tegeh, \& Prabawa. (2015). Desain Pesan Kajian Analisis Desain Visual Teks dan Image. Graha Ilmu.

Surjono, H. D. (2017). Multimedia Pembelajaran Interaktif Konsep dan Pengembangan. UNY Press.

Susilowati, T., \& Muryati, S. (2021). Pembelajaran Daring melalui Model Problem Based Learning ( PBL ) pada Tema 5 Pahlawanku Subtema 1 Jasa Para Pahlawan Kelas Iv Semester 1 Sd Negeri Cabean Tahun Pelajaran $2020 \quad$ / 2021. PPG, http://journal.univetbantara.ac.id/index.php/jppg/article/view/1384.

Tegeh, I. M., \& Kirna, I. M. (2010). Metode Penelitian Pengembangan Pendidikan. Singaraja: Universitas 


\section{Pendidikan Ganesha.}

Tegeh, I. M., Simamora, A. H., \& Dwipayana, K. (2019a). Pengembangan Media Video Pembelajaran dengan Model Pengembangan 4D pada Mata Pelajaran Agama Hindu. Mimbar Ilmu, 24(2), 158. https: //doi.org/10.23887/mi.v24i2.21262.

Tegeh, Simamora, \& Dwipayana. (2019b). Pengembangan Media Video Pembelajaran dengan Model Pengembangan 4D pada Mata Pelajaran Agama Hindu. Jurnal Mimbar Ilmu, 24(2), 158-166. https: //dx.doi.org/10.23887/mi.v24i2.21262.

Windhiyana, E. (2020). Dampak Covid-19 terhadap Kegiatan Pembelajaran Online di Perguruan Tinggi Kristen di Indonesia. Perspektif Ilmu Pendidikan, 34(1), 1-8. https://doi.org/10.21009/pip.341.1.

Yahya, N. (2014). Model Pembelajaran Berbasis Proyek Berbantuan Media Kultur Jaringan untuk Meningkatkan Ativitas dan Kreativitas Siswa Kelas XII IPA2 SMA Negeri 1 Bangsri. Jurnal Pendidikan IPA Indonesia, 3(2), 154-159. https://doi.org/10.15294/jpii.v3i2.3115.

Yustina, Syafii, W., \& Vebrianto, R. (2020). The Effects of Blended Learning and Project-Based Learning on Pre-Service Biology Teachers' Creative Thinking Skills through Online Learning in the COVID-19 Pandemic. Jurnal Pendidikan IPA Indonesia, 9(3), 408-420. https://doi.org/10.15294/jpii.v9i3.24706. 